\title{
Petrogenesis of mafic-ultramafic and associated rocks along Sa Kaeo and Pattani Sutures, Thailand
}

\author{
Thitiphan Assawincharoenkija ${ }^{\mathrm{a}, *}$, Chakkaphan Sutthirat ${ }^{\mathrm{a}}$, Piyaphong Chenrai ${ }^{\mathrm{a}}$, Suwapak Imsamut ${ }^{\mathrm{b}}$, \\ Punya Charusiri ${ }^{\mathrm{b}}$ \\ ${ }^{a}$ Applied Mineral and Petrology of Special Task Force for Activating Research (AMIN STAR), Department \\ of Geology, Faculty of Science, Chulalongkorn University, Bangkok 10330 Thailand \\ b Department of Mineral Resources, Thung Phaya Thai, Ratchathewi, Bangkok 10400 Thailand
}

*Corresponding author, e-mail: thitiphan.a@chula.ac.th

Received 10 Dec 2020

Accepted 12 Jun 2021

\begin{abstract}
Mafic-ultramafic rocks and other types of rocks were collected from Sa Kaeo and Pattani sutures. Both sutures are suspected to be a connection between the Nan suture in Northern Thailand and the Bentong-Raub suture that runs across the southern border of Thailand to Malaysia. Rocks were collected from four locations along Sa Kaeo suture: Khao Priwan (Location 1), Wang Somboon (Location 2), Khao Pun-Soi Dao (Location 3), and Pong Nam Ron (Location 4) and one location from Sai Buri River along Pattani suture (Location 5). Both Sa Kaeo and Pattani sutures mainly consist of serpentinite, gabbro, diabase, basalt, pillow basalt, limestone interbedded with sandstone, and shale. Geochemically, the basalts (found in Locations 2, 3) are believed to erupt from the back-arc basin, which is related to within-plate alkali composition; the serpentinite (found in Location 1) is believed to be originated similarly through the process of mafic magma; whereas the pillow basalt taken from Pattani suture (Location 5) is tholeiitic MORB derived from the mantle. All the collected rocks from Sa Kaeo suture appear to be originated from a back-arc basin that had undergone ancient subduction during the Permian-Triassic period. While rock suits in Pattani suture show a similar serpentinized peridotite accumulation process, the found pillow basalts also suggest a possible close relationship to MORB and the ocean floor.
\end{abstract}

KEYWORDS: basalt, ultramafic rock, ophiolite, suture, tectonic

\section{INTRODUCTION}

The regional tectonic setting of Thailand and its vicinity consist of two main microcontinents, namely Shan-Thai and Indochina (Fig. S1). The Shan-Thai block covers Eastern Myanmar, Western Thailand, Western Peninsular, and Northern Sumatra; whereas the Indochina block occupies Eastern Thailand, Laos, Cambodia, and parts of Vietnam. Both terranes are completely allochthonous to Asia and amalgamated together in the Late Triassic $[1,2]$.

During the Paleotectonic event, two small oceanic blocks built up between the Shan-Thai and the Indochina microcontinents, namely Nakhon Thai and Lampang-Chiang Rai terranes. Nakhon Thai terrane, mainly characterized by the ocean floor, is located to the west of Indochina craton. Lampang-Chiang Rai terrane, significantly occupied by volcanic arc, situates on the east of Shan-Thai craton [2]. Both Nakhon Thai and Lampang-Chiang
Rai terranes appear to have welted along the main geological suture so-called "Nan suture" (Fig. S1) $[3,4]$. During the Triassic Period, multiple episodes of movements and collisions of tectonic blocks in mainland SE Asia were emerging [5]; contemporaneously, Nakhon Thai and Lampang-Chiang Rai terranes were reaching to high latitude of the northern hemisphere, after which they did not move further. As a consequence, they underwent tremendous compressive stress and were subsequently led to upthrusting and suturing along three particular zones in Thailand: Eastern Lampang-Chiang Rai, converging onto Nakhon Thai terrane along the main Nan suture; Eastern Nakhon Thai, thrusting onto Western Indochina and caused Loei suture; and paleotethys between Shan-Thai and LampangChiang Rai, whose closure was well-completed as partly indicated by Chiang Mai suture [2] (Fig. S1). These sutures, are suggested through exposures of Upper Paleozoic mafic-ultramafic rock that are considered as related part of the ophiolite suite $[4,6,7]$ 
(Fig. S1).

The ophiolite suites are made up of rock forms which represent the lithologic units that make up the oceanic crust and upper mantle [8-11]. Dredging steep scarps on oceanic ridges and fracture zones, for example, consist of yielded pillow basalts, mafic volcanic breccia, diabase dikes, gabbro, greenstone, serpentinite, and various forms of massive and layered cumulate ultramafic rocks $[8,9]$.

Besides, four Permian-Jurassic Volcanic Belts in Thailand are crucial evidence to confirm our suspected sutures. Geographically from west to east, these volcanic belts are Chiang Rai-Chiang Mai, Chiang Khong-Tak, Nan-Sa Kaeo, and LoeiPhetchabun-Phai Sali Volcanic Belts $[12,13]$. In existing studies, ophiolite suite and volcanic rocks along these suspected sutures have not much been investigated in details. The reason could be due to poor exposures, caused by the tropical climate of the country, that are scattered only in few restrictive areas.

Regarding the Nan suture zone, it starts from Nan Province and continues southwestward to Uttaradit Province along the Nan River in Northern Thailand $[3-6,14]$. The suture extends southward and merges with Sa Kaeo suture along Sa KaeoChanthaburi Provinces in the eastern region of the country before its extension disappears into the Northern Gulf of Thailand (Fig. S1a) [15]. Another suture appears on the Southern Gulf, crossing the southern border of the country and passes through Malaysia; this suture was named Bentong-Raub suture in Malaysian border [16]. The suture carried another name, Pattani suture, given by Thai geologists [2] (Fig. S1b), and it is suspected to be part of Nan-Sa Kaeo suture.

In the ophiolite suites of this study, serpentinites, mafic-ultramafic intrusives, pillow basalts, and related sedimentary rocks were found sparsely in few collapsed zones along the long extended NanSa Kaew suture. For the aspects of petrochemistry and mineral chemistry, only ophiolite samples in Nan-Uttaradit Provinces were been investigated [17]; and zircon dating was investigated following Yang [18]. This paper, therefore, aims to study petrology and geochemistry of ophiolite suites along the Sa Kaeo suture within Sa Kaeo and Chanthaburi Provinces and the Pattani suture in Narathiwat Province. Rock samples were collected from the study areas where exposures of basalts, mafic-ultramafic intrusives, and other related rocks were suspected to be part of ophiolite suites.

\section{GEOLOGICAL SETTING AND STUDY AREAS}

As shown in geologic maps (Fig. S1), the study areas in Sa Keao-Chanthaburi and Narathiwat Provinces are occupied by sedimentary, metamorphic, and igneous rocks ranging in age from Carboniferous to Quaternary. Regarding details of the rock formation in these two areas, there are, however, slight differences, as summarized below.

\section{Sa Kaeo-Chanthaburi study area}

Hada [19] categorized Sa Kaeo-Chanthaburi area as southern segment of the Nan-Uttaradit suture in Eastern Thailand. Rock formations along this area, clearly formed along the main NW-SE structure, were subdivided into two parallel belts: the western belt of Chanthaburi chert-clastic sequence and the eastern belt of serpentinite Thung Kabin mélange [19-21]. The Thung Kabin mélange is characterized by strongly foliated serpentinite including various kinds of blocks. Due to their sparse small exposures, they are mapped within the boundary of Permian limestone in which serpentinite and basalt samples from Locations 1 and 2 are located (Fig. S1a). This Permian limestone contains widely massive and bedded, gray to black, fossiliferous limestone. On the other hand, the western Chanthaburi chertclastic belt, mainly characterized by an alternation of red bedded chert units and clastic unit, is comparable to Carboniferous-Permian chert formation (Fig. S1a); this is where samples from Location 3 (gabbro and basalt samples) and Location 4 (diabase) are situated. Details of all locations may be somewhat, however, different from the regional description. This is likely due to the complexity of geological structure related to the collision. Triassic greywacke, or "Pong Nam Ron Formation", is also evidently much more voluminous exposures in the area. This sandstone unit represents syncollisional sediments along the remnant basin of the collision zone between the Shan-Thai and the Indochina [22]. Quaternary sediments, mainly gravel and lateritic soil, are restrictively deposited along colluvial, channel, and terrace particularly in the southwestern part. Igneous activities are indicated by Triassic hornblende-biotite granitic rock and Quaternary olivine basalt. The hornblendebiotite granitic rocks comprise medium- to coarsegrained granite, microgranite, subvolcanic granite (or phophyritic rhyorite), porphyritic granite, and biotite-tourmarine granite that are related to tectonic collision [23]. The Quaternary olivine basalts appear to have erupted during Cenozoic extension, 
the last tectonic active in Thailand.

\section{Narathiwat study area}

Marine sedimentary sequences, ranging from Carboniferous to Triassic, expose around Sai Buri River in Sukhirin District, Narathiwat Province where Pattani suture is suspected to originate along the main NE-SW geologic structure. CarboniferousPermian rocks can be subdivided into metamorphic formation and sedimentary rock sequence. The Carboniferous-Permian metamorphic rocks are composed of slaty shale, phyllitic shale, phyllite, and hornfel; whereas the sedimentary rocks comprise sandstone, tuffaceous sandstone, conglomerate, and some metasedimentary rocks (quartzite). The western part of the area is mainly occupied by Permian-Triassic shale and siltstone; on the other hand, the eastern part consists widely of conglomerate and conglomeratic sandstone of the same age. In addition, Triassic cherts usually have white to smoky white expose in the middle part. In the latter part, Permian-Triassic serpentinite and basalt appear to have formed NE-SW parallel belts. Podiform chromite and pillow lava are recognized in these serpentinite and basalt, respectively [7]; and this is considered as indication of the geologic suture. Both rock types, serpentinite and basalt, were collected for this study, as labeled with Location 5 (Fig. S1b). Quaternary sediments, mainly colluvial and terrace deposits, cover in some eastern and western areas.

\section{MATERIALS AND METHODS}

Samples were taken from five localities in Sa Kaeo suture (Locations 1 to 4) along the border between Sa Kaeo and Chanthaburi Provinces (Fig. S1a) and in Pattani suture (Location 5) along a segment of Sai Buri River in Narathiwat Province (Fig. S1b). All samples were taken for petrographic investigations before selectively sampling for chemical analyses of whole-rocks and minerals. X-ray Fluorescence (XRF) Spectrometer (a Bruker AXS S4 PIONEER) at Department of Geology, Faculty of Science, Chulalongkorn University (CU) was applied for major and minor analyses. These quantitative analyses were operated at $220 \mathrm{~V}, 50 \mathrm{~Hz}, 8 \mathrm{kVA}$. In addition, Inductively Coupled Plasma-Optical Emission Spectroscopy (ICP-OES) at the National Centre of Excellent for Environmental and Hazardous Waste Management, CU was adopted for examination of trace elements and rare earth elements (REE). Calibration with natural rock standards supplied by the US Geological Survey (USGS) and the Geological Survey of Japan (GSJ) was applied during the whole-rock analyses. Moreover, loss on ignition (LOI) was measured by weighing rock powders compared before and after $3 \mathrm{~h}$ ignition at $950^{\circ} \mathrm{C}$ in RHF 14-3 220 V electric furnace. Mineral chemistry analyses were carried out using Electron Probe Micro-Analyzer (EPMA: Model JEOL JXA-8100) at the Department of Geology, CU with a focused beam $(<1 \mu \mathrm{m})$ at $15 \mathrm{kV}$ about $20 \mathrm{nA}$ operating condition; and pure oxide and natural mineral standards were used for calibration.

\section{RESULTS AND DISCUSSION}

\section{Field investigation and petrography}

Location 1 (Khao Priwan serpentinite): Serpentinites usually have grayish-green to green colors with white patches and are moderate to strong weather. The foliated feature can be found following the main NW-SE structural direction in some outcrops. The found chromite embedded within these serpentinites is similar to a meter across podiform (Fig. S2a); this affirms a relation to oceanic crust $[8,9]$. Microscopically, fibrous forms of serpentine are often shown, whereas mesh texture of serpentine is merely present in some samples (Fig. 1a). Both lizardite and antigorite are identified using XRD from these serpentines. Although relict texture of mafic minerals is often present, remaining olivine and pyroxenes (Fig. 1b) can be found in very few samples. Opaque minerals (Fig. 1a) are present in the forms of single-crystal and accumulated veinlets of which EPMA analysis indicates high iron and chromite composition (not shown here). In addition, other greenschist assemblages, particularly chlorite and talc, are also present as accessory.

Location 2 (Wang Somboon basalt): Over two meter thick of black basaltic layers are found, and pillow forms are also present (Fig. S2b). Green and grayish-green serpentines can be partially found along the cracks. The hypocrystalline porphyritic texture is commonly recognized; and plagioclase phenocrysts $(0.1-0.5 \mathrm{~mm})$ embed in very finegrained groundmass $(<0.1 \mathrm{~mm})$ of plagioclase microlite, pyroxene, and glassy materials (Fig. 1c). The finding of secondary minerals, resulted from alteration such as serpentine, chlorite, and epidote, has also been registered.

Location 3 (Khao Pun and Soi Dao basalt): Various types of rock were found at mélange outcrop at Khao Pun [24]. Brownish-red chert interbedded with grayish-black siliceous shale and 


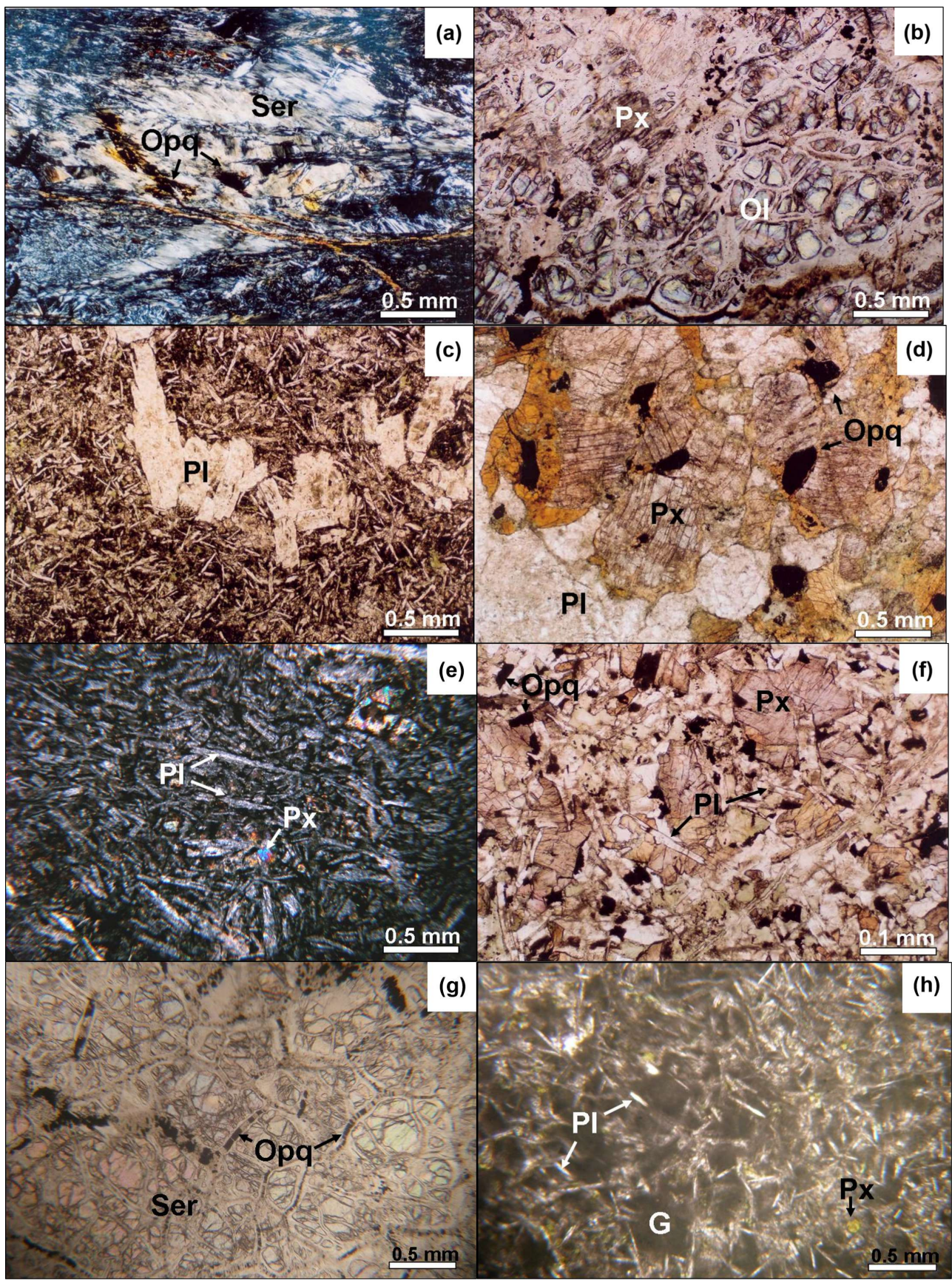

Fig. 1 Photomicrographs of Location 1: (a) showing fibrous serpentine with a few opaque grains (XPL), (b) mesh texture with relic olivine and pyroxene found in a few serpentinite samples (PPL); Location 2: (c) fine-grained plagioclase laths phenocrysts accumulated in plagioclase microlites, clinopyroxenes, and glassy materials (PPL); Location 3: (d) mediumgrained gabbro containing anhedral-subhedral crystals of abundant plagioclase and pyroxene with smaller opaque grains (PPL), (e) basalt sample showing less alteration of plagioclase laths forming trachytic texture with tiny pyroxene grains and dark glassy matrix (XPL); Location 4: (f) fine-grained diabase showing subophitic texture of plagioclase lath enclosed partially by subhedral pyroxene with some opaque mineral and less glass (PPL); Location 5: (g) mesh texture of serpentine and some opaque veinlets in serpentinite (PPL), ( h) finer-grained basalt containing plagioclase microlite and highly altered brown materials mixing between pyroxene and glass (PPL). Mineral abbreviations: serpentine (Ser), olivine (Ol), pyroxene (Px), opaque (Opq), and glass (G). 
marble is contacted by gabbro (Fig. S2c) showing holocrystalline, intergranular and medium-grained textures. The mineral assemblage of gabbro mainly comprises anhedral-subhedral pyroxene and plagioclase (Fig. 1d). In addition, we are able to confirm the relation of basaltic exposures to limestone platform, thanks to the discovery of them in this area. Particular outcrops located at Khao Rang area contain limestone beds aligning in N-S directions with steeply dipping, where many basaltic nodules, ranging from 1 to $30 \mathrm{~cm}$ in diameter, are found embed in these limestones (Fig. S2d). Fusulinacean fossils found in limestone is Lower-Middle Permian in age [25]. Based on microscopy, these basaltic exposures often present hypocrystalline and microporphyritic textures. Plagioclase laths often form trachytic texture (Fig. 1e), whereas pyroxene grains are highly altered to chlorite and epidote. Olivine microphenocrysts are also found as relic crystals.

Location 4 (Pong Nam Ron): Massive and thick-bedded limestone interbedded with sandstone and shale are the main rock units being penetrated by diabase (mafic igneous) (Fig. S2e). However, disordered orientations of these rocks seem to have been involved by tectonic force that had kneaded these rocks together. Although the diabase layers are more resistant than the sediment layers, they are partly altered by serpentinization. They show hypocrystalline texture that contains interstitial and subophitic textures. Plagioclase laths are commonly enclosed by subhedral pyroxene (Fig. 1f). These rocks also contain accessory opaque minerals and less amount of glassy materials.

Location 5 (Sai Buri River): Serpentinite and basalt exposed along the river and adjacency (Fig. S2f) were collected. Serpentinite is mostly characterized by deep green to dark grey colors. Relics of initial coarse-grained minerals are found. Dolomite and talc have been detected in some samples. Outer edges of some specimen have pale greenish chlorite. These minerals are suspected to have formed during the retrograde metamorphism or late alteration process. Microscopically, all samples contain predominately serpentine of various forms along with fibrous features that are significantly present (Fig. 1g). Fibroblastic and microfibrous textures sometimes occupy throughout the samples. In addition, mesh texture is found in relicts of olivine and/or pyroxene crystals. For all samples, antigorite and lizardite are identified based on XRD patterns. Opaque minerals are also recognized as particularly formed as veinlets.

Basaltic rocks discovered in Location 5 appear to have pillow form. Aphanitic texture with cracks and different degrees of alteration is also present. They have greenish grey to dark grey colors. Microscopically, they have slightly different grain sizes but similar mineral assemblages with highly to moderately altered signatures that are typically distinguished in all samples. Equigranular and hypocrystalline textures without phenocryst and xenolith are common in all samples. Features of plagioclase microlites intergrowth with anhedral pyroxenes, likely subophitic texture, are shown in coarser-grain samples which may be originally similar to diabase. On the other hand, finer-grained basalts usually present plagioclase microlites embed in brown alteration materials that are derived from pyroxene and glassy material (Fig. 1h). Opaque minerals are also identified as accessory. Apart from this, secondary minerals (e.g., epidote and serpentine) are usually present along the edge and the cracks.

\section{Mineral chemical analyses}

EPMA analyses of mafic minerals and plagioclase were selected, as shown in Tables S1 and S2, respectively. Olivine remains in serpentinite have quite high Fo content (about 90\%), and this is associated with clinopyroxenes and orthopyroxene which all have high Mg proportion (Fig. 2a). These indicate ultramafic composition [26,27], probably cumulated peridotite. Regarding clinopyroxenes of other rocks, they are quite similar in composition. $\mathrm{CaO}$ contents appear to increase from basalt in Location 5 (16.56-18.94\%), basalt in Location 2 (17.60-20.36\%), diabase in Location 4 (20.09$20.56 \%)$ and gabbro in Location 3 (22.22-23.00\%), respectively.

Moreover, Fe contents of diabasic clinopyroxenes (Location 4) are higher than those of gabbro (Location 3), which may be due to the differentiation of magma. Unfortunately, basalts from Location 3 are highly altered fine-grained rocks, according to which it could not be analyzed by EPMA; otherwise, the correlation could have been confirmed. Despite this, a sufficient proof is still available from the finding of pillow basalts in Location 2 .

Plagioclases of all basalt samples have queer compositions with unusual high $\mathrm{Na}$ content (Table S2). Their recalculated formulas do not fit well with feldspar chemistry. This is probably due to the alteration related to seawater. However, some plagioclase grains in basalts from Location 2 still show deviation from Ab-rich to moderate 
(a)

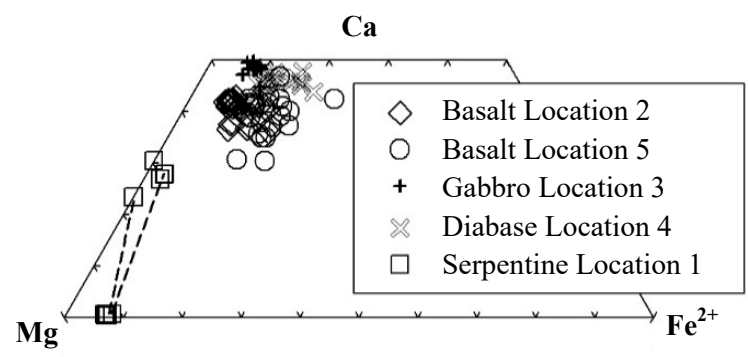

(b)

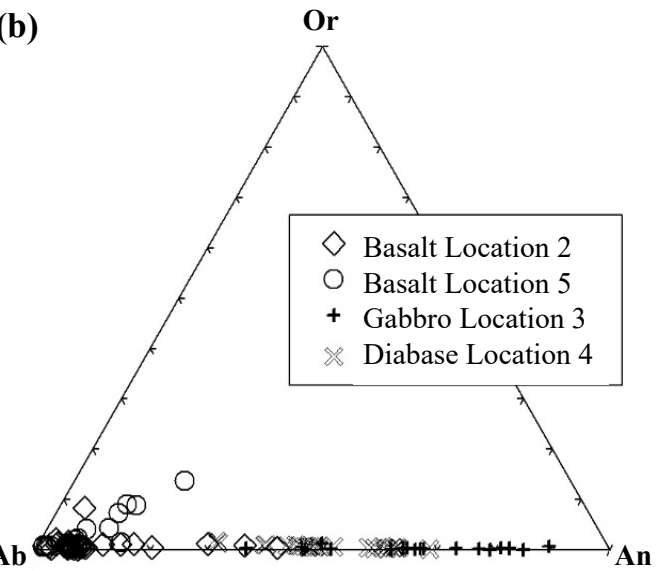

Fig. 2 (a) Atomic Ca-Mg-Fe plots of pyroxenes in rock collection. (b) End-member plots of plagioclases in rock collection.

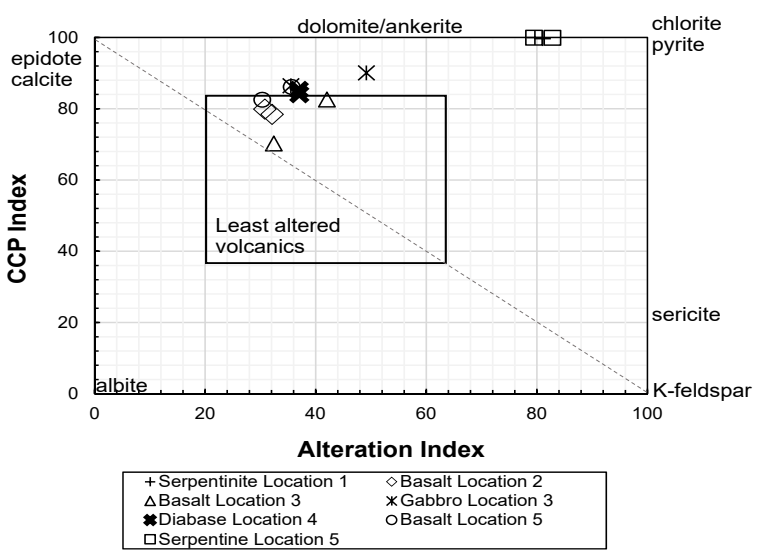

Fig. 3 Diagram of alteration index (AI) and CCP index [28]. Data of basalt are plotted in least altered box ranging from basalt compositions.

An contents, of which the amount has reduced when compared with that in diabase and gabbro of Locations 4 and 5 (Fig. 2b). The result likely indicates that plagioclase fractionation may have been taking place continuously among these rock suits.

\section{Whole-rock geochemistry}

Basalts and mafic intrusives are the most abundant samples found in all locations. Therefore, wholerock geochemistry is a more appropriate aspect in order to conduct an investigation based on these rocks. To qualify altered rock that would be part of the examination, the alteration index box plot is modified from the two alteration indexes: the Ishikawa alteration index (AI) (Eq. 1) and the chlorite-carbonate-pyrite index (CCPI) (Eq. 2) [28].

$$
\begin{aligned}
\mathrm{AI} & =\frac{100\left(\mathrm{~K}_{2} \mathrm{O}+\mathrm{MgO}\right)}{\left(\mathrm{K}_{2} \mathrm{O}+\mathrm{MgO}+\mathrm{Na}_{2} \mathrm{O}+\mathrm{CaO}\right)} \\
\mathrm{CCPI} & =\frac{100(\mathrm{MgO}+\mathrm{FeO})}{\left(\mathrm{K}_{2} \mathrm{O}+\mathrm{MgO}+\mathrm{Na}_{2} \mathrm{O}+\mathrm{FeO}\right)}
\end{aligned}
$$

According to the result shown in Table 1, it is noted that these rocks are mostly plotted within limits of the least-altered rocks (Fig. 3), except for diabase, gabbro, and serpentinite that are plotted out of the box. This is due to the fact that the alteration box plot is suitable for felsic to intermediate rocks [28].

Chemical compositions of serpentinite are highly modified from the source. The representative analyses of all rock types are summarized in Table 1 and Table S3. Due to the highly modified chemical composition of serpentinites, it would not be appropriate to compare them with other rocks. Variations of major and trace elements were correlated between basalts and related mafic intrusives. Selective major oxides $\left(\mathrm{Al}_{2} \mathrm{O}_{3}, \mathrm{Fe}_{2} \mathrm{O}_{3}\right.$, and $\left.\mathrm{CaO}\right)$ and trace elements ( $\mathrm{Cr}, \mathrm{Zr}$, and $\mathrm{Y}$ ) plotted against $\mathrm{MgO}$ contents (Fig. 4) are used for general comparison. As a result, basalts from all locations, as well as related intrusives, have shown some interesting trends as follows: decreasing trends of $\mathrm{Al}_{2} \mathrm{O}_{3}, \mathrm{Fe}_{2} \mathrm{O}_{3}, \mathrm{Zr}$, and $\mathrm{Y}$ against increasing of $\mathrm{MgO}$; whereas $\mathrm{CaO}$ appears to be increasing.

Discrimination and tectono diagrams plotting of major and trace elements are selected for presentation and interpretation (Fig. 5). According to $\mathrm{SiO}_{2}$-alkali plots [29], all basalt samples fall 

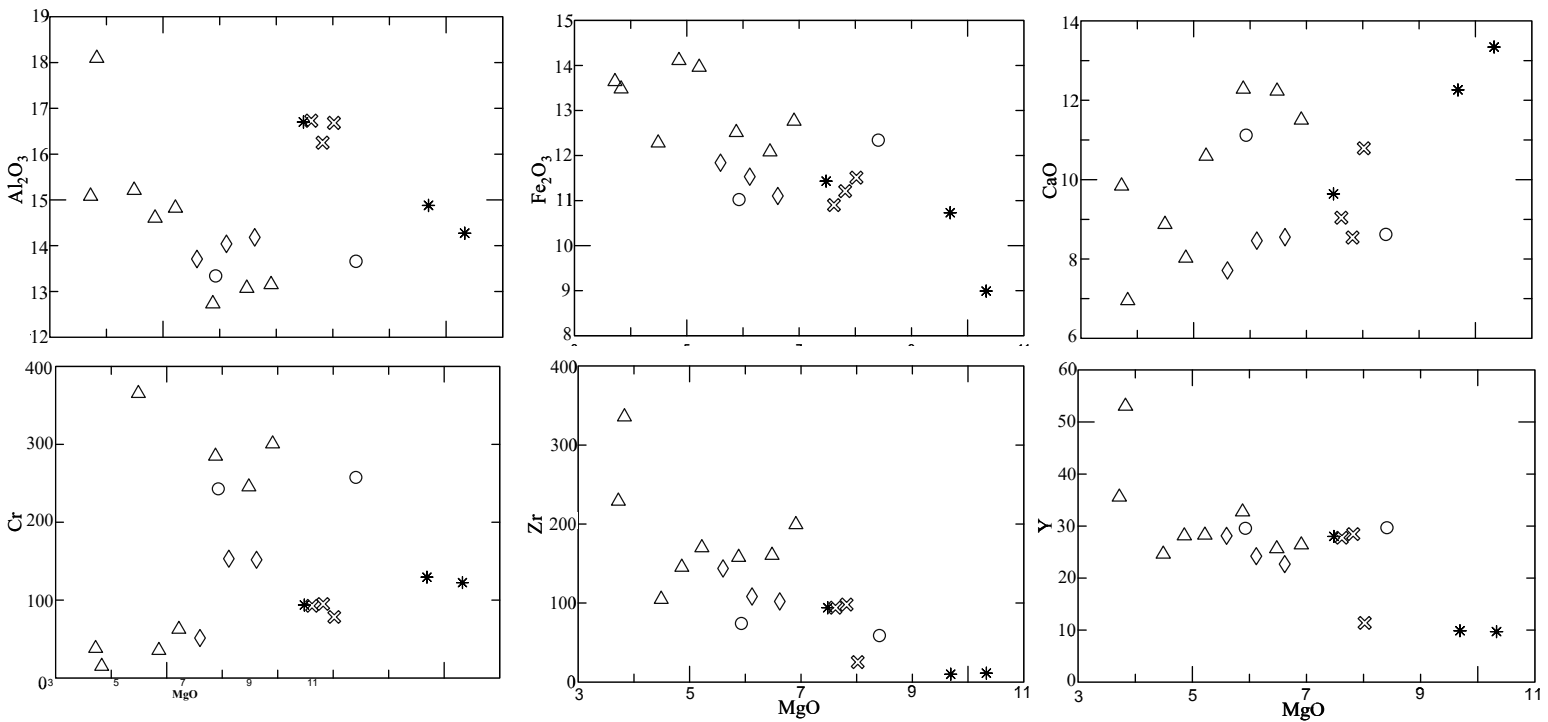

$\diamond$ Basalt Location $2 \triangle$ Basalt Location $3 \bigcirc$ Basalt Location 5 * Gabbro Location $3 \bowtie$ Diabase Location 4

Fig. 4 Variation diagrams of selective major and trace elements plotted against MgO contents of rock samples collected along Sa Kaeo and Pattani sutures.

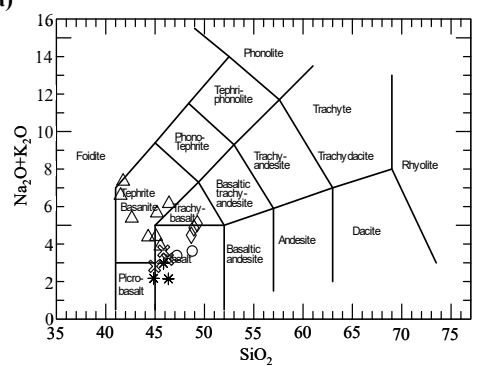

(d)

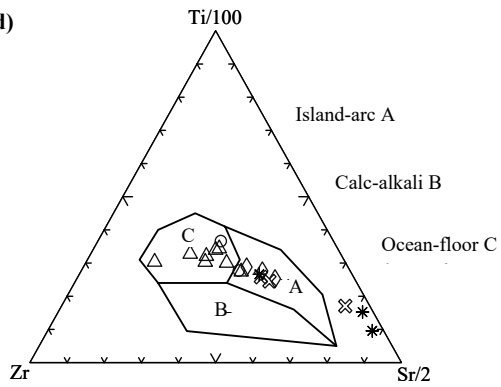

(b)
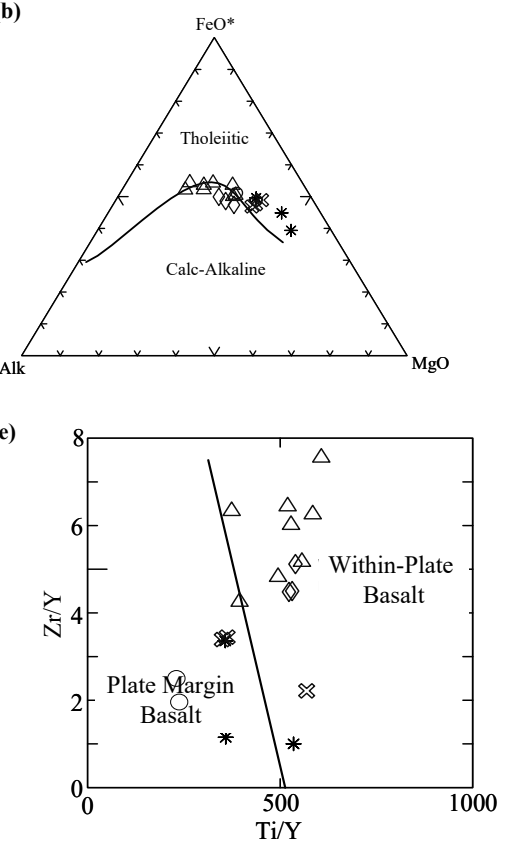
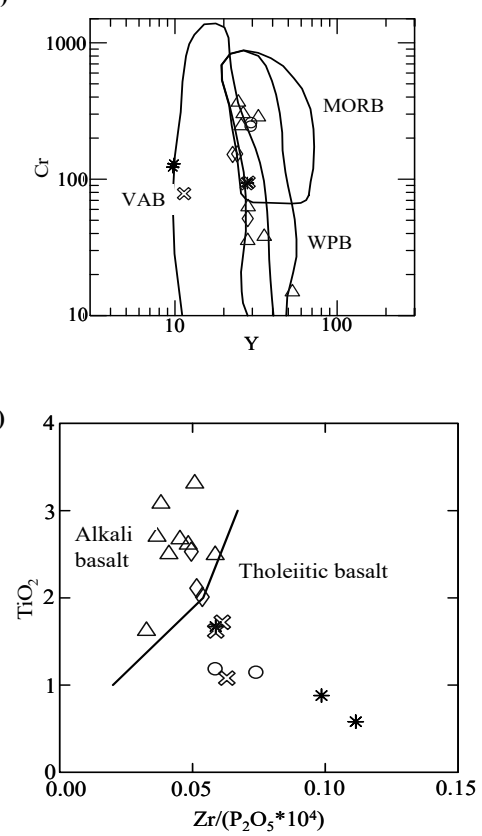

$\diamond$ Basalt Location $2 \triangle$ Basalt Location $3 \bigcirc$ Basalt Location 5 * Gabbro Location 3 \& Diabase Location 4

Fig. 5 Rock samples collected along Sa Kaeo and Pattani sutures are plotted on discrimination and tectono diagrams: (a) Alkali-SiO ${ }_{2}$ discrimination plots of rock samples; (b) $\mathrm{MgO}-\mathrm{FeO}-A l k a l i$ triangular plots indicating magma series; (c) Cr-Y tectono diagram of rock samples; (d) Tectono diagram plotted between $\mathrm{Sr} / 2$, Ti/100 and $\mathrm{Zr}$ of rock samples; (e) $\mathrm{Zr} / \mathrm{Y}$ against Ti/Y plots of rock samples ranging between plate margin and within plate; and (f) $\mathrm{TiO}_{2}-\mathrm{Zr} /\left(\mathrm{P}_{2} \mathrm{O}_{5} * 10^{4}\right)$ diagram showing variation between tholeiitic and alkali compositions of rock samples. 

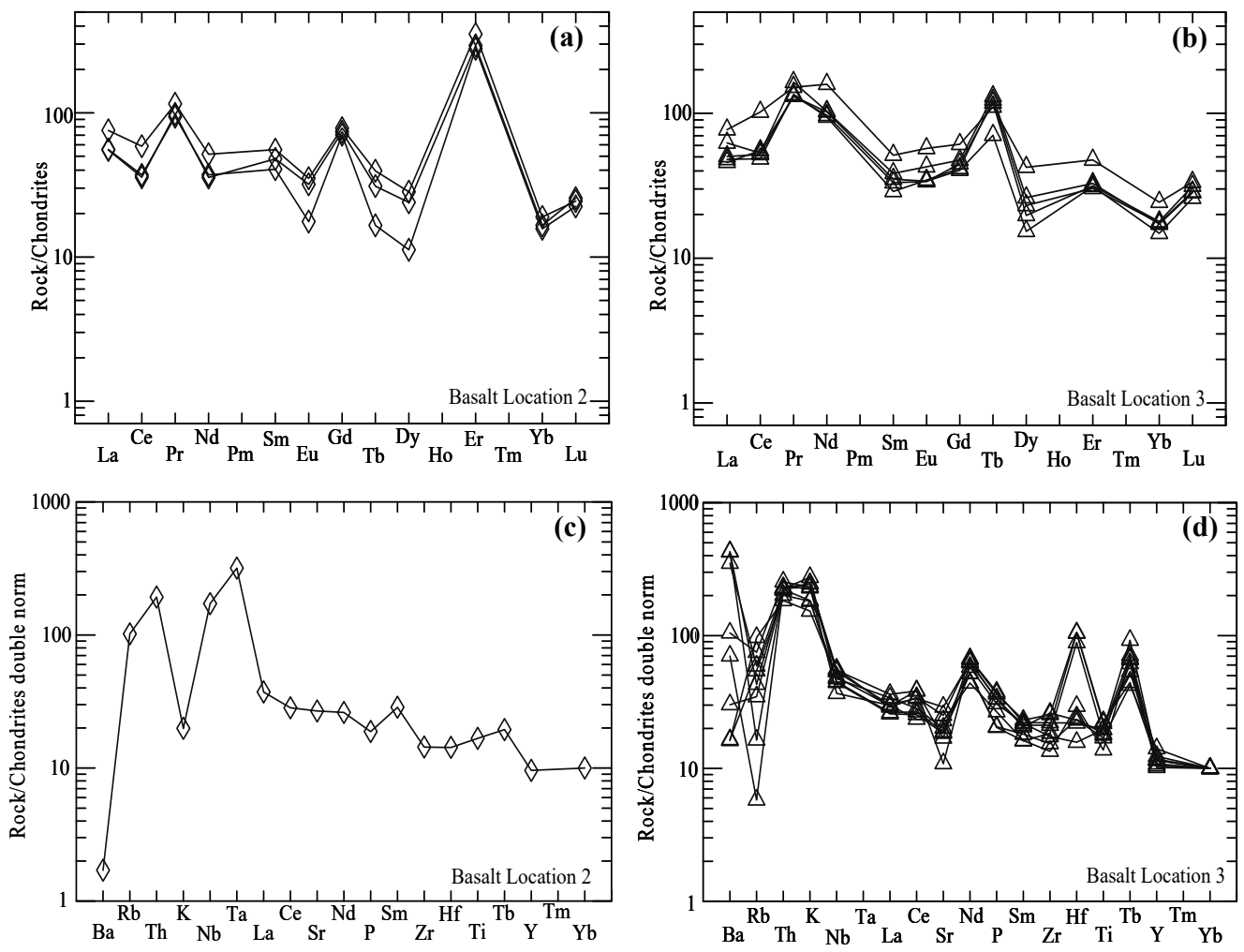

Fig. 6 (a,b): Chondrite-normalized REE [35] plots of rock samples collected along Sa Kaeo and Pattani sutures showing zigzag patterns with different declination between LREE and HREE. (c,d): Chondrite-normalized multi-trace element spidergrams [36] of rock samples collected along Sa Kaeo and Pattani sutures showing high contents of Th and Ta and variations of the other elements.

Table 1 Representative whole-rock analyses of basalts and associated gabbro, diabase, and serpentinite along Sa Kaeo and Pattani sutures.

\begin{tabular}{|c|c|c|c|c|c|c|c|c|c|c|c|c|c|c|}
\hline \multirow{3}{*}{ Name } & \multirow{2}{*}{\multicolumn{2}{|c|}{$\begin{array}{l}\text { Location } 1 \\
\text { Serpentinite }\end{array}$}} & \multirow{2}{*}{\multicolumn{2}{|c|}{$\begin{array}{c}\text { Location } 2 \\
\text { Basalt }\end{array}$}} & \multicolumn{4}{|c|}{ Location 3 Gabbro } & \multirow{2}{*}{\multicolumn{2}{|c|}{$\begin{array}{c}\text { Location } 4 \\
\text { Diabase }\end{array}$}} & \multicolumn{4}{|c|}{ Location 5} \\
\hline & & & & & Bas & & $\mathrm{Gal}$ & bro & & & $\mathrm{Ba}$ & alt & Serp & Itinite \\
\hline & S2-2 & S5-3 & B1-2 & B2-1 & SDBS1-1 & SDBS6 & KPBS-1 & KPBS-3 & SSBS-2 & SSBS-4 & PB1-1 & PB1-3 & S2-2 & S3/4-5 \\
\hline $\mathrm{SiO}_{2}$ & 42.08 & 40.19 & 48.93 & 48.67 & 41.76 & 45.55 & 46.35 & 45.86 & 45.87 & 46.26 & 47.26 & 48.81 & 40.30 & 37.33 \\
\hline $\mathrm{TiO}_{2}^{2}$ & 0.02 & 0.11 & 2.11 & 2.01 & 3.31 & 2.70 & 0.58 & 1.67 & 1.72 & 1.62 & 1.18 & 1.14 & 0.02 & 0.27 \\
\hline $\mathrm{Al}_{2} \mathrm{O}_{3}$ & 0.85 & 2.56 & 14.04 & 14.18 & 18.09 & 12.73 & 14.27 & 16.70 & 16.25 & 16.73 & 13.66 & 13.34 & 0.64 & 6.74 \\
\hline $\mathrm{Fe}_{2} \mathrm{O}_{3}$ & 8.83 & 8.09 & 11.53 & 11.10 & 13.48 & 12.51 & 8.99 & 11.43 & 11.21 & 10.90 & 12.34 & 11.02 & 7.90 & 8.88 \\
\hline $\mathrm{MnO}^{3}$ & 0.10 & 0.11 & 0.14 & 0.16 & 0.08 & 0.16 & 0.15 & 0.19 & 0.20 & 0.18 & 0.25 & 0.15 & 0.07 & 0.09 \\
\hline $\mathrm{MgO}$ & 34.58 & 35.19 & 6.12 & 6.62 & 3.83 & 5.88 & 10.33 & 7.48 & 7.82 & 7.62 & 8.41 & 5.93 & 38.47 & 34.69 \\
\hline $\mathrm{CaO}$ & 0.01 & 2.33 & 8.46 & 8.55 & 6.95 & 12.28 & 13.34 & 9.64 & 8.54 & 9.04 & 8.62 & 11.12 & nd. & 0.05 \\
\hline $\mathrm{K}_{2} \mathrm{O}$ & 0.01 & 0.02 & 1.11 & 0.22 & 4.16 & 3.48 & 0.22 & 0.29 & 0.57 & 0.40 & 0.19 & 0.31 & nd. & nd. \\
\hline $\mathrm{Na}_{2} \mathrm{O}$ & 0.01 & 0.14 & 3.75 & 4.25 & 3.18 & 0.40 & 1.92 & 2.68 & 3.05 & 2.79 & 3.17 & 3.29 & 0.07 & 0.05 \\
\hline $\mathrm{P}_{2} \mathrm{O}_{5}$ & 0.01 & 0.01 & 0.21 & 0.19 & 0.66 & 0.43 & 0.01 & 0.16 & 0.16 & 0.16 & 0.10 & 0.10 & 0.01 & 0.12 \\
\hline $\mathrm{LOI}^{5}$ & 12.47 & 10.60 & 3.36 & 3.81 & 4.26 & 3.59 & 3.63 & 3.70 & 4.40 & 4.11 & 3.85 & 3.76 & 12.84 & 12.00 \\
\hline Total & 98.97 & 99.35 & 99.76 & 99.77 & 99.76 & 99.71 & 99.80 & 99.79 & 99.80 & 99.80 & 99.02 & 98.98 & 100.31 & 100.21 \\
\hline
\end{tabular}

nd. = non-detected.

with areas of picro-basalt, basalt, trachy-basalt, and tephrite basanite ranging in alkali content. Alkali contents increase from gabbro, diorite, and basalts collected from Locations 5, 2, and 3, respectively (Fig. 5a). MgO-FeO-Alkali triangular plots [30] also show variation between tholeiitic and calc-alkali series (Fig. 5b).

The other diagrams, including $\mathrm{Sr} / 2-\mathrm{Ti} / 100$ $\mathrm{Zr}$ [31] and Y vs. Cr [32], also reveal the variation of these mafic rocks ranging from MORB to ocean floor, island arc, and within plate (Fig. 5cd). Besides, $\mathrm{Ti} / \mathrm{Y}$ vs. $\mathrm{Zr} / \mathrm{Y}[33]$ in Fig. 5e and $\mathrm{Zr} /\left(\mathrm{P}_{2} \mathrm{O}_{5}{ }^{*} 10^{4}\right)$ 
vs. $\mathrm{TiO}_{2}$ [34] in Fig. $5 f$ indicate that compositions of gabbro (Location 3), diabase (Location 4), and basalt (Location 5) are continuously changing from plate margin/tholeiitic magma to within plate/alkali magma of basalts (Locations 2 and 3). This evidence implies rock distributions along the suture and the presence of connection between island arc and back arc basin.

Spidergrams of chondrite-normalized REE and multi-trace elements using chondrite compositions of [35] and [36], respectively (Fig. 6), can confirm the above interpretation. Decreasing LREE to HREE patterns of basalts in Locations 2 and 3 with close La:Lu ratio of about 2:1 indicates a lower degree of partial melting (Fig. 5a). High contents of Th and $\mathrm{Ta}$ in normalized trace element pattern of all rock types would imply crustal involvement, probably also magma contamination or hybrid mixing of subduction material (Fig. 5b). Moreover, basalt in Location 3 with higher $\mathrm{K}$ may imply magma differentiation to higher alkali composition of backarc ocean floor (within plate) [13].

\section{CONCLUSION}

Based on geochemistry, pillow basalts from Sai Buri River in Sukhirin District, Narathiwat Province, and those from Pattani suture (Location 5) appear to be mantle-derived magma, which is related to tholeiitic MORB. Plagioclase compositions also indicate alteration that may have taken place during the uplift of serpentinite in the area. This serpentinite appears to have accumulated from mafic magma, which was partially melted from upper mantle as evidenced by REE and trace element patterns. This evidence, therefore, introduces a destructive plate margin of subduction in the area during PermianTriassic period. As a similar result, serpentinite collected along Sa Kaeo suture (Location 1) is believed to be originated by the same process of mafic magma accumulation. However, basalts in the nearby areas (Locations 2 and 3) appear to have erupted from the back-arc basin. Based on their geochemistry, the result likely indicates within-plate alkali compositions. In terms of geochemistry and mineral chemistry, these basalts have close relation with diabase and gabbro. They may have undergone successive fractionation processes after hugely partial melting of the mantle due to subduction. The crustal array, as recorded in REE and multi-trace elements, firmly supports this theory.

In conclusion, rock collections along Sa Kaeo suture in Chanthaburi and Sa Kaeo Provinces, Eastern Thailand appear to be originated from a back- arc basin that had undergone ancient subduction in Permian-Triassic period. Whereas the rock suits in Pattani suture in Southern Thailand show a similar accumulation process of serpentinized peridotite. However, the pillow basalts of the suits reveal that they may also have a close relation to the MORB and the ocean floor.

\section{Appendix A. Supplementary data}

Supplementary data associated with this article can be found at http://dx.doi.org/10.2306/ scienceasia1513-1874.2021.071.

Acknowledgements: This research project was financially supported by the Thailand Research Fund (TRF). All research facilities were provided by the Faculty of Science and the National Centre of Excellence for Environmental and Hazardous Waste Management, Chulalongkorn University.

\section{REFERENCES}

1. Bunopas S (1981) Paleogeographic history of western Thailand and adjacent parts of South-East Asia: a plate tectonics interpretation. $\mathrm{PhD}$ thesis, Victoria Univ of Wellington, New Zealand.

2. Charusiri P, Daorerk V, Archibald D, Ken-ichiro H, Amphiwan T (2002) Geotectonic evolution of Thailand: a new synthesis. $J$ Geol Soc Thai 1, 1-20.

3. Barr SM, Macdonald AS (1987) Nan River suture zone, Northern Thailand. Geology 15, 907-910.

4. Singharajwarapan S, Berry R (2000) Tectonic implications of the Nan Suture Zone and its relationship to Sukhothai Fold Belt, Northern Thailand. $J$ Southeast Asian Earth Sci 18, 663-673.

5. Sone M, Metcalfe I (2008) Parallel Tethyan sutures in mainland SE Asia: New insights for Palaeo-Tethys closure. Compt Rendus Geosci 340, 166-179.

6. Crawford AJ, Panjasawatwong Y (1996) Ophiolites, ocean crust, and the Nan Suture in NE Thailand. In: Lee TY (ed) Proceedings of the International Symposium on lithosphere dynamics of East Asia-program, Taipei.

7. Malaysian and Thai Working Groups (2002) Geology of the Batu Melintang-Sungai Kolok Transect Area along the Malaysia-Thailand Border. A Technical Report of Cooperation, Department of Mineral Resources, Bangkok.

8. Coleman RG, Irwin WP (1974) Ophiolites and ancient continental margins. In: Burk CA, Drake CL (eds) The Geology of Continental Margins, SpringerVerlag, New York, pp 921-931.

9. Dilek Y, Furnes H (2014) Ophiolites and their origins: Deep biosphere record of in situ oceanic lithosphere and ophiolites. Elements 10, 93-100.

10. Pearce JA (2014) Immobile elements fingerprinting of ophiolites. Elements 10, 101-108. 
11. Pearce JA (2014) Geochemical fingerprinting of the earth's oldest rocks. Geology 42, 175-176.

12. Jungyusuk N, Khositanont S (1992) Volcanic rocks and associated mineralization in Thailand. Potential for future development, In: Proceedings of the National Conference on Geologic Resource of Thailand, Department of Mineral Resources, Bangkok, pp 522-538.

13. Phajuy B, Singtuen V (2019) Petrochemical characteristics of Tak volcanic rocks, Thailand: Implication for tectonic significance. ScienceAsia 45, 350-360.

14. Metcalfe I (2021) Multiple Tethyan ocean basins and orogenic belts in Asia. Gondwana Res. [in press]

15. Sone M, Metcalf I, Chaodumrong P (2012) The Chanthaburi terrane of southeastern Thailand: Stratigraphic confirmation as a disrupted segment of the Sukhothai Arc. J Asian Earth Sci 61, 16-32.

16. Tan BK (1996) Suture zone in peninsular Malaysia and Thailand: implications for palaeotectonic reconstruction of Southeast Asia. $J$ Southeast Asian Earth Sci 13, 243-249.

17. Orberger B, Lorand JP, Girardeau J, Mercier JCC, Pitragool S (1995) Petrogenesis of ultramafic rocks and associated chromitites in the Nan Uttaradit ophiolite, Northern Thailand. Lithos 35, 153-182.

18. Yang W, Qian X, Feng Q, Shen S, Chonglakmani C (2016) Zircon U-Pb geochronological evidence for the evolution of the Nan-Uttaradit suture in northern Thailand. J Earth Sci 27, 378-390.

19. Hada S, Bunopas S, Ishii K, Yoshikura S (1999) Riftdrift history and the amalgamation of Shan-Thai and Indochina/East Malaya Blocks. In: Dheeradilok P, et al (eds) Proceedings of the International Conference on Stratigraphy and Tectonic Evolution of Southeast Asia and the South Pacific, Department of Mineral Resources, Bangkok, Thailand, pp 273-286.

20. Hara H, Ito T, Tokiwa T, Kong S, Lim P (2020) The origin of the Pailin crystalline complex in western Cambodia, and back-arc basin development in the Paleo-Tethys Ocean. Gondwana Res 82, 299-316.

21. Udchachon M, Thassanapak H, Burrett C (2018) Early Permian radiolarians from the extension of the Sa Kaeo Suture in Cambodia - tectonic implications. Geol Mag 155, 1449-1464.

22. Chutakositkanon V, Hisada K (2008) Tectonostratigraphy of the Sa Kaeo-Chanthaburi Accretionary Complex, Eastern Thailand: Reconstruction of Tectonic Evolution of Oceanic Plate-Indochina Collision. In: Proceedings of the International Symposia on Geoscience Resources and Environments of Asian Terranes (GREAT 2008), Bangkok, Thailand.

23. Salyapong S, Fontaine H, Putthapiban P, Lamjuan A (1997) Geology of the Eastern Thailand (route no. 1). In: Guidebook for Excursion of the International
Conference on Stratigraphy and Tectonic Evolution of Southeast Asia and the south Pacific, Department of Mineral Resources, Bangkok, Thailand.

24. Chutakositkanon V, Charusiri P, Sashida K (2000) Lithostratigraphy of Permian marine sequences, Khao Pun Area, central Thailand: Paleoenvironments and tectonic history. Isl Arc 9, 173-187.

25. Fontaine H, Salyapongse S (1997) Biostratigraphy of East Thailand. In: Dheeradilok P, et al (eds) Proceedings of the International Conference on Stratigraphy and Tectonic Evolution of Southeast Asia and the South Pacific, Department of Mineral Resources, Bangkok, Thailand, pp 73-82.

26. Liu ZB, Li JC, Zhao T, Song Y, Yuan GL, Lin Y, Shao HS (2020) Serpentinisation and magnetite formation in the Angwu ultramafic rocks from the central Bangong-Nujiang suture zone, Tibetan Plateau. Geol J 55, 1283-1299.

27. Evans BW, Hattori K, Baronnet A, (2013) Serpentinite: what, why, where? Elements 9, 99-106.

28. Large R, Gemmell JB, Paulick H (2001) The Alteration Box Plot: A Simple Approach to Understanding the Relationship between Alteration Mineralogy and Lithogeochemistry Associated with Volcanic-Hosted Massive Sulfide Deposits. Econ Geol 96, 957-971.

29. LeBas MJ, LeMaitre RW, Streckeisen A, Zanettin B (1986) A chemical classification of volcanic rocks based on the total alkali silica diagram. $J$ Pet 27, 745-750.

30. Irvine TN, Baragar WRA (1971) A guide to the chemical classification of the common volcanic rocks. Can J Earth Sci 8, 523-548.

31. Pearce JA, Cann JR (1973) Tectonic setting of basic volcanic rocks determined using trace element analysis. Earth Planet Sci Lett 19, 290-300.

32. Pearce JA (1982) Trace element characteristics of lavas from destructive plate margins. In: Thorpe RS (ed) Andesites: Orogenic Andesites and Related Rocks, Wiley, Chichester, New York, pp 525-548.

33. Pearce JA, Gale GH (1977) Identification of oredeposition environment from trace-element geochemistry of associated igneous host rocks. Geol Soc Spec Publ 7, 14-24.

34. Winchester JA, Floyd PA (1977) Geochemical discrimination of different magma series and their differentiation products using immobile elements. Chem Geol 20, 325-343.

35. Sun S, McDonough WF (1989) Chemical and isotopic systematics of oceanic basalts: implications for mantle composition and processes. In: Saunders $\mathrm{AD}$, Norry MJ (eds) Magmatism in the Ocean Basins, Geol Soc Spec Publ 42, pp 313-345.

36. Thompson RN (1982) Magmatism of the British Tertiary Volcanic Province. Scott J Geol 18, 49-107. 


\section{Appendix A. Supplementary data}

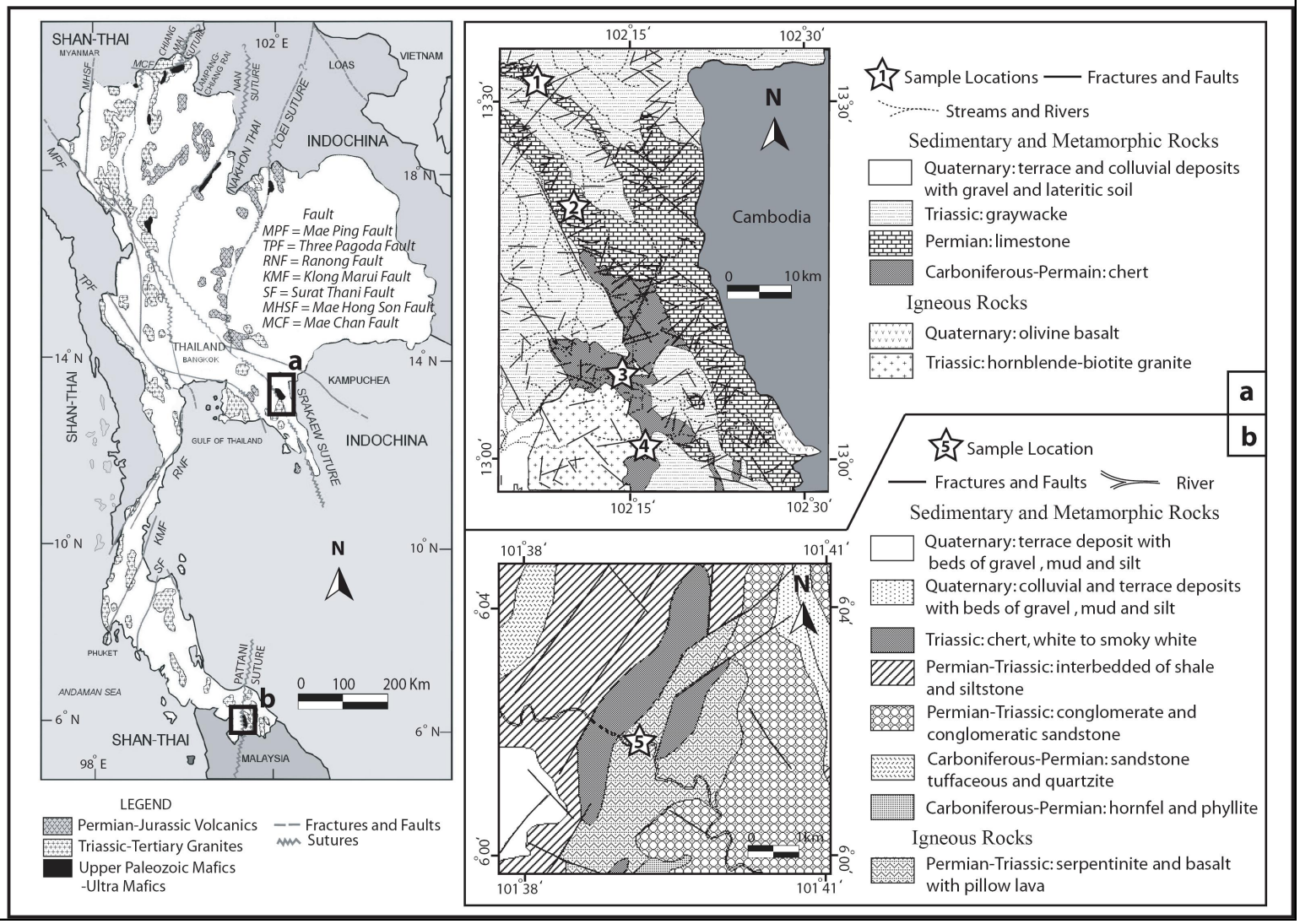

Fig. S1 Index tectonic map showing main tectonic features of Thailand (modified after [2]) and geologic maps (modified after [7, 22-24]) showing detailed geologic setting around the sample locations along (a) Sa Kaeo suture in the East and (b) Pattani suture in the South. 


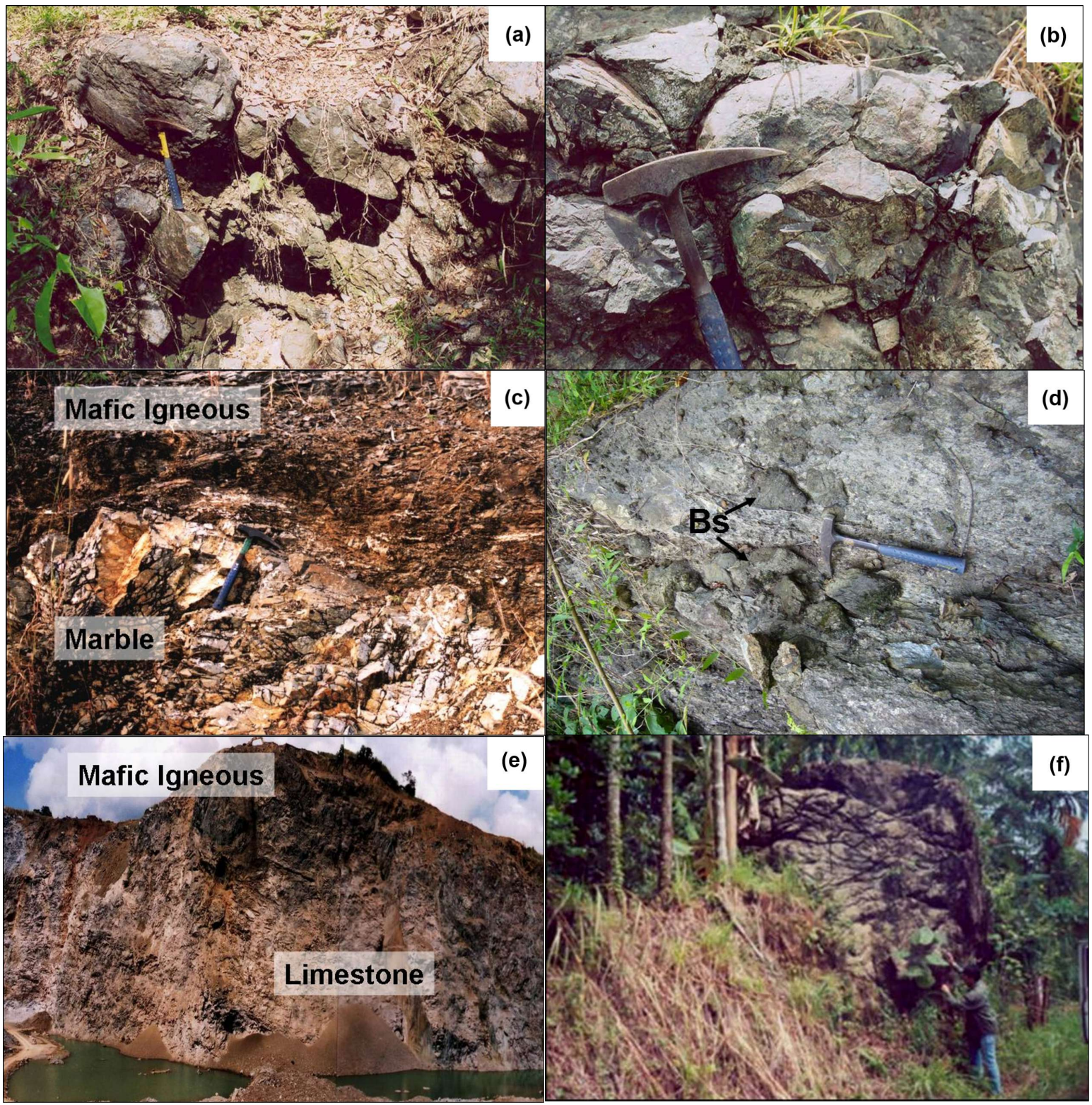

Fig. S2 Location 1: (a) chromite, likely podiform, embedded in softer matrix of serpentinite; Location 2: (b) an outcrop of pillow basalts showing greenish serpentinization partly along cracks; Location 3: (c) a mélange outcrop at Khao Pun hill showing block of marble associated with altered mafic igneous rock, (d) basalt (Bs) nodules embedded in limestone platform around Soi Dao area; Location 4: (e) dark mafic igneous layers adulterated with paler limestone and clastic rock layers at Sahasila Mine; Location 5: (f) serpentinite outcrop exposed along Sai Buri river. 


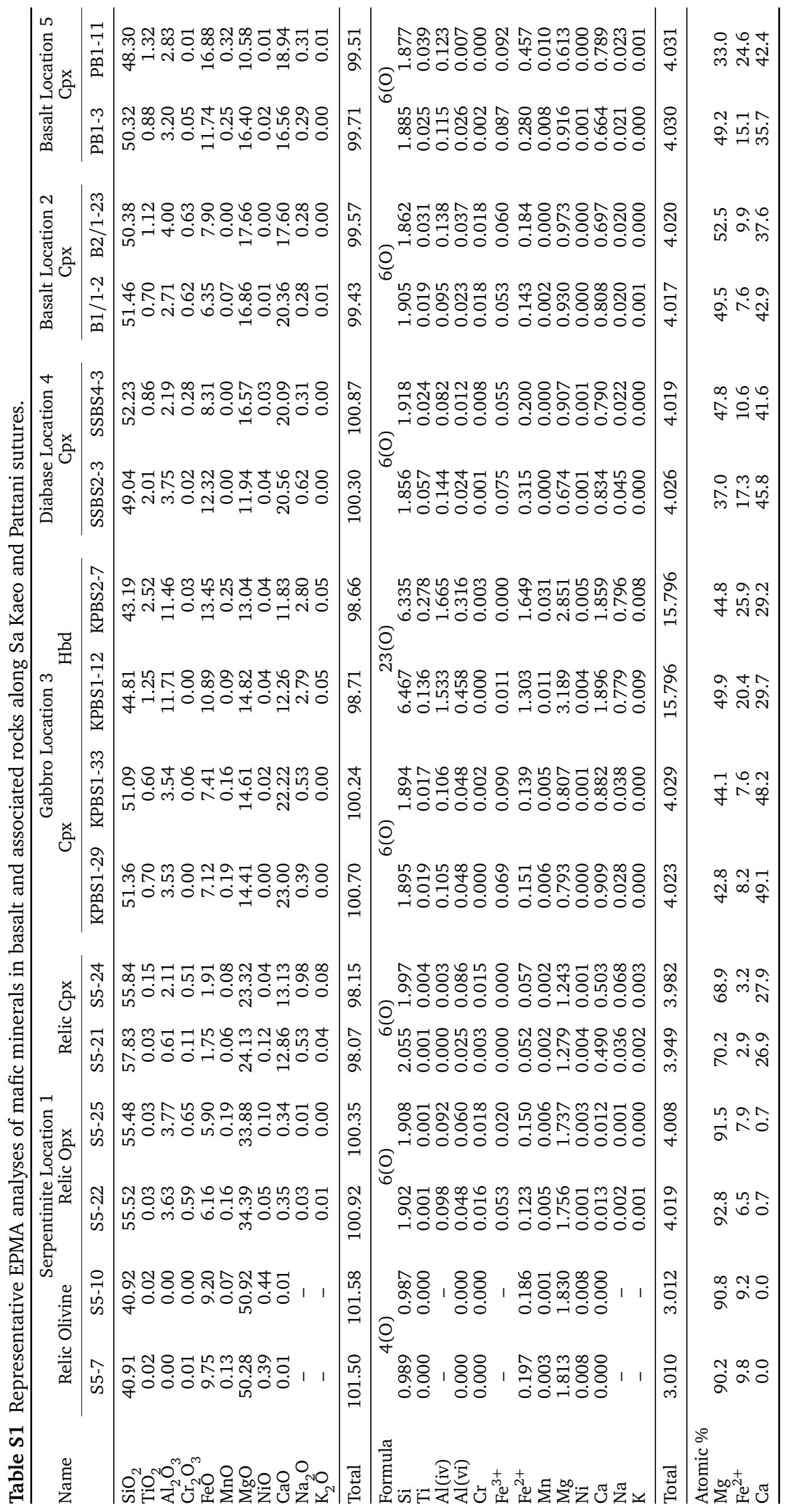




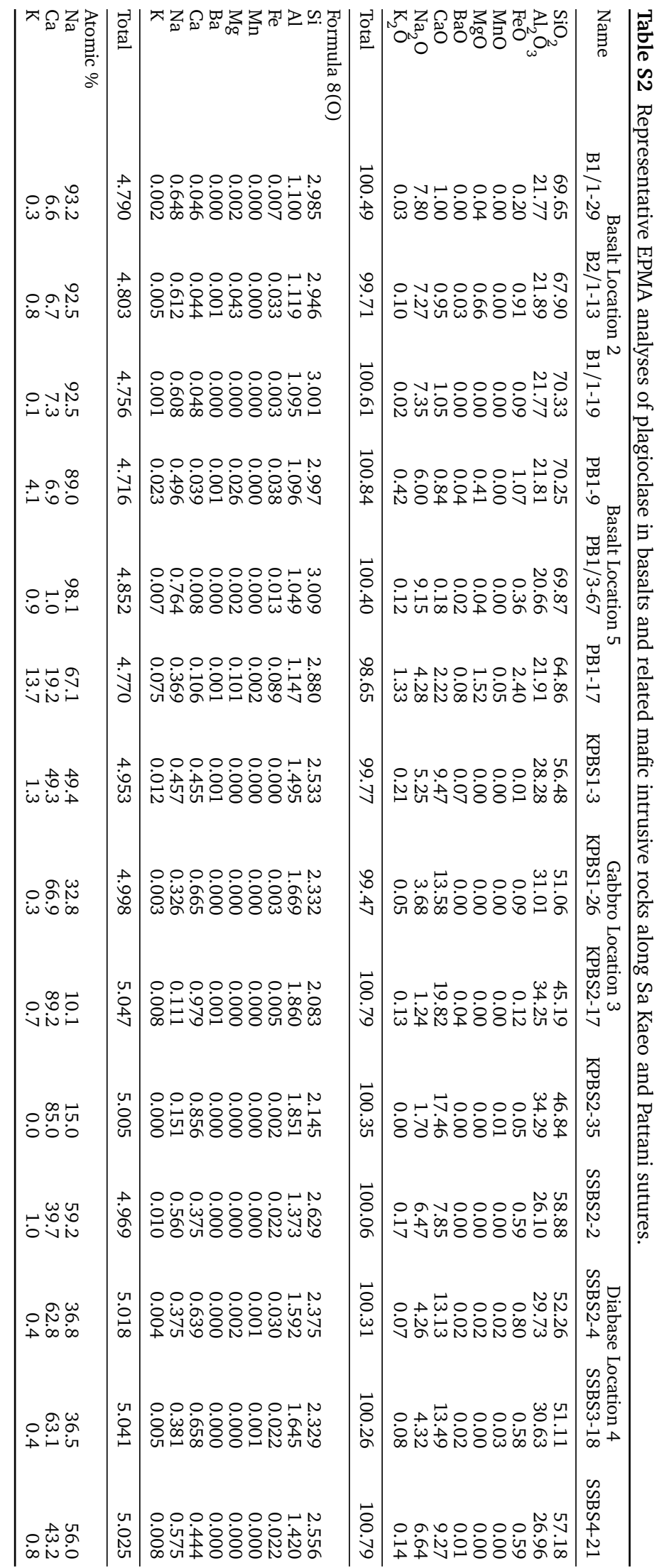


Table S3 Representative whole-rock analyses of basalts and gabbro, diabase, and serpentinite along Sa Kaeo and Pattani Sutures.

\begin{tabular}{|c|c|c|c|c|c|c|c|c|c|c|c|c|c|c|}
\hline \multirow{3}{*}{ Name } & \multirow{2}{*}{\multicolumn{2}{|c|}{$\begin{array}{c}\text { Location } 1 \\
\text { Serpentinite }\end{array}$}} & \multirow{2}{*}{\multicolumn{2}{|c|}{$\begin{array}{c}\text { Location } 2 \\
\text { Basalt }\end{array}$}} & \multirow{2}{*}{\multicolumn{4}{|c|}{ Basalt Location 3 Gabbro }} & \multirow{2}{*}{\multicolumn{2}{|c|}{$\begin{array}{c}\text { Location } 4 \\
\text { Diabase }\end{array}$}} & \multicolumn{4}{|c|}{ Location 5} \\
\hline & & & & & & & & & & & \multicolumn{2}{|c|}{ Basalt } & \multicolumn{2}{|c|}{ Serpentinite } \\
\hline & S2-2 & S5-3 & B1-2 & B2-1 & SDBS1-1 & SDBS6 & KPBS-1 & KPBS-3 & SSBS-2 & SSBS-4 & PB-1-1 & PB-1-3 & S2-2 & S3/4-5 \\
\hline $\mathrm{Ba}$ & 1.1 & 0.8 & 3.5 & 3.5 & 210.5 & 150.8 & 14.8 & 2.7 & 16.4 & 16.6 & 17.2 & 105.6 & 1.2 & 1.1 \\
\hline Co & 176 & 126 & 48 & 57 & 37 & 56 & 69 & 64 & 65 & 78 & 90 & 76 & 150 & 138 \\
\hline $\mathrm{Cr}$ & 2005 & 7625 & 153 & 152 & 15 & 285 & 123 & 94 & 95 & 93 & 258 & 243 & 1838 & 1150 \\
\hline $\mathrm{Cu}$ & 7.3 & 5.0 & 88.4 & 97.4 & 31.3 & 45.1 & 155.7 & 69.9 & 65.3 & 62.8 & 89.5 & 75.9 & 7.1 & 2.4 \\
\hline $\mathrm{Ga}$ & 2.4 & nd. & 7.4 & 8.7 & 28.1 & 28.9 & 5.0 & 7.7 & 7.9 & 7.5 & 7.3 & 7.0 & 1.6 & 3.6 \\
\hline Hf & 2.1 & 1.6 & 1.3 & 2.2 & 8.7 & 4.2 & 5.5 & 1.7 & 3.3 & 2.5 & 2.0 & 6.1 & 2.3 & 3.7 \\
\hline $\mathrm{Nb}$ & 0.0 & 0.0 & 73.4 & 68.3 & 32.0 & 22.0 & 18.4 & 56.5 & 58.0 & 55.3 & 40.3 & 39.5 & nd. & 8.1 \\
\hline $\mathrm{Ni}$ & 4256 & 6487 & 81 & 81 & 41 & 1998 & 100 & 68 & 58 & 66 & 128 & 109 & 3076 & 1331 \\
\hline $\mathrm{Pb}$ & 25.9 & nd. & 29.1 & 19.1 & nd. & 1.9 & 10.2 & 17.2 & 8.9 & 32.1 & 3.9 & 11.0 & 17.0 & 6.7 \\
\hline $\mathrm{Rb}$ & 7.7 & nd. & 152.7 & 27.9 & 63.8 & 25.3 & 94.3 & 29.7 & 60.0 & 38.2 & 36.6 & 99.6 & nd. & nd. \\
\hline Sc & 6.8 & nd. & 28.3 & 29.7 & 17.4 & 28.3 & 55.0 & 33.6 & 36.4 & 33.3 & 41.4 & 41.9 & 7.1 & 6.7 \\
\hline Sr & 5.9 & nd. & 447.4 & 509.1 & 241.1 & 315.4 & 636.7 & 365.0 & 439.8 & 371.9 & 129.4 & 211.7 & 2.9 & 4.1 \\
\hline $\mathrm{Ta}$ & 2.5 & nd. & 5.6 & 11.6 & nd. & nd. & 2.5 & 7.2 & 5.6 & 4.7 & 6.7 & 5.2 & 1.8 & 1.5 \\
\hline Th & 11.2 & 0.3 & 11.5 & 11.2 & 14.5 & 11.2 & 8.9 & 11.2 & 11.0 & 10.0 & 12.7 & 11.0 & 9.8 & 11.4 \\
\hline $\mathrm{U}$ & 15.6 & nd. & 24.9 & 23.3 & nd. & nd. & 23.3 & 24.7 & 24.3 & 24.8 & 26.8 & 24.9 & 13.5 & 15.1 \\
\hline V & 16.1 & 33.4 & 129.5 & 123.3 & 28.0 & 257.9 & 110.2 & 129.4 & 122.9 & 116.9 & 167.0 & 167.3 & 19.1 & 14.7 \\
\hline W & 1.1 & nd. & 1.8 & 1.1 & nd. & nd. & 2.2 & 2.6 & 3.0 & 3.2 & 3.8 & 2.5 & 1.7 & 1.4 \\
\hline Y & 0.5 & 0.6 & 24.2 & 22.7 & 53.0 & 32.7 & 9.7 & 28.0 & 28.5 & 27.8 & 29.7 & 29.6 & 2.2 & 11.8 \\
\hline $\mathrm{Zn}$ & 44.0 & nd. & 59.1 & 54.8 & nd. & nd. & 41.5 & 47.5 & 53.1 & 55.2 & 62.4 & 55.1 & 34.9 & 42.8 \\
\hline $\mathrm{Zr}$ & 2.4 & 1.1 & 108.3 & 102.1 & 335.7 & 157.7 & 11.2 & 94.0 & 98.0 & 94.1 & 58.8 & 74.1 & 11.6 & 86.8 \\
\hline \multicolumn{15}{|l|}{ REE } \\
\hline $\mathrm{La}$ & 0.3 & nd. & 13.1 & 13.2 & 18.3 & 14.8 & 5.1 & 7.6 & 7.3 & 7.0 & 6.5 & 6.8 & nd. & 0.5 \\
\hline $\mathrm{Ce}$ & 0.0 & nd. & 21.9 & 22.7 & 62.5 & 32.5 & 0.8 & 8.8 & 9.2 & 12.0 & 6.2 & 8.8 & nd. & 5.2 \\
\hline $\mathrm{Pr}$ & 4.7 & 0.4 & 9.3 & 8.9 & 14.4 & 15.6 & 5.6 & 8.7 & 7.5 & 7.2 & 7.5 & 8.2 & 4.4 & 5.2 \\
\hline $\mathrm{Nd}$ & nd. & nd. & 16.6 & 17.3 & 74.2 & 48.3 & 1.6 & 10.3 & 10.3 & 11.9 & 5.8 & 7.2 & 0.5 & 3.2 \\
\hline $\mathrm{Sm}$ & 1.0 & nd. & 7.3 & 6.2 & 7.9 & 5.9 & 3.0 & 6.0 & 5.4 & 5.4 & 5.2 & 5.9 & nd. & 1.8 \\
\hline $\mathrm{Eu}$ & nd. & 0.0 & 1.9 & 1.0 & 3.3 & 2.5 & 0.7 & 1.1 & 0.9 & 0.9 & 0.1 & 0.6 & nd. & 0.2 \\
\hline $\mathrm{Gd}$ & 8.9 & nd. & 15.2 & 14.5 & 12.6 & 9.8 & 9.2 & 14.5 & 14.2 & 13.4 & 13.8 & 13.3 & 8.2 & 10.3 \\
\hline $\mathrm{Tb}$ & 0.5 & nd. & 1.2 & 0.6 & 4.1 & 4.9 & 0.7 & 1.4 & 0.7 & 0.6 & 1.6 & 1.1 & 0.4 & 0.6 \\
\hline Dy & nd. & nd. & 6.1 & 2.9 & 10.8 & 6.7 & nd. & 2.6 & 6.5 & 7.8 & 2.3 & 0.7 & nd. & 1.3 \\
\hline Ho & nd. & nd. & nd. & nd. & nd. & nd. & nd. & nd. & nd. & nd. & nd. & nd. & nd. & nd. \\
\hline Er & 0.2 & nd. & 48.5 & 46.0 & 7.9 & 5.4 & 15.1 & 41.6 & 42.0 & 37.2 & 26.1 & 24.7 & 0.1 & 5.7 \\
\hline $\mathrm{Tm}$ & nd. & nd. & nd. & nd. & nd. & nd. & nd. & nd. & nd. & nd. & nd. & nd. & nd. & nd. \\
\hline $\mathrm{Yb}$ & 0.4 & 0.2 & 2.8 & 2.7 & 4.1 & 2.9 & 1.6 & 3.7 & 3.8 & 3.7 & 4.3 & 4.0 & 0.4 & 2.1 \\
\hline $\mathrm{Lu}$ & 0.4 & 0.1 & 0.7 & 0.6 & 0.9 & 0.7 & 0.4 & 0.6 & 0.6 & 0.6 & 0.7 & 0.7 & 0.3 & 0.4 \\
\hline
\end{tabular}

nd. = non-detected. 